\section{แแนแแแแแแแแแแนแแนแแ} 論 文

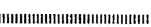

\section{気泡流における球と液体間の熱伝達}

(C) 1987 ISIJ

\title{
Heat Transfer between Liquid and a Sphere in Bubbling Flow
}

\author{
Manabu IGUCHI, Munekazu OHMI, Masamichi YariYama and Jun-ichi TanI
}

\begin{abstract}
Synopsis :
The characteristics of bubbling flow of air and water approaching an ice sphere were made clear by means of the photographic recording method and the electroresistivity probe technique. The melting process of the ice sphere was recorded by a video camera and the local Nusselt number $N u_{\theta}$ was determined from a change in local radius with the aid of a digitizer supported by a large scale computer. Here, the initial radius of sphere was used as a representative length. The measured values of $N u_{\theta}$ increased appreciably all over the surface of the sphere compared to the values in single phase flow of water. As a result, the mean Nusselt number $\bar{N} u$ averaged over the surface also increased. The increasing rate of $\bar{N} u$ decreased gradually with the passing frequency of bubbles $\bar{n}_{b}$ and finally the effect of bubbles on $\bar{N} u$ diminished. The effect of the Reynolds number based on the cross-sectional mean velocity of water and the initial diameter of sphere decreased with an increase in $\bar{n}_{b}$.
\end{abstract}

Key word : steelmaking; injection ; bubbling flow ; heat transfer ; Nusselt number ; sphere.

\section{1. 緒言}

省資源，省エネルギーの観点から，最近低品位鉱の利 用や大量のスクラップの再利用を可能にするために，ガ スを鋼浴に吹込み攪挥することによつて金属の溶解を促 進させる技術を利用した種々の精錬法の開発が試みられ ている ${ }^{122)}$. しかし，従来ガス吹込みが攪拌に及ぼす影 響についてはかなり詳しく研究されている3)が，金属の 溶解速度に及ほす気泡の直接の影響に関する研究は少な

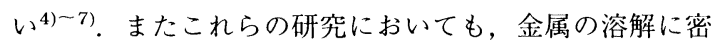
接な関係のある球の周りの気泡を含む流れ場の特性が十 分把握されていないために，系統的知見を得るには至つ ていない.

本研究ではこの課題の基礎的研究として, 水と水球を 用いたコールドモデル実験を対象とするが，まず気泡形 状と大きさ, 気泡が水球にあたる際の角度と頻度などの 基本的特性を調べたうえで, 溶解初期における水球の ヌッセルト数を評価し, 気泡の衝突頻度と水球の初期直 径に基づくレイノルズ数が水球の熱伝達ひいては溶解に 及ばす影響を明らかにする。

\section{2. 実験装置と測定方法}

\section{$2 \cdot 1$ 溶解実験}

実験に用いる水球は，2つに割つたピンポン球に直径 $2 \mathrm{~mm}$ の支持棒を取り付けたものを型として, 冷蔵庫の 製水室で作製した。水球に気泡が混入した場合, 溶解速 度が影響される危険性があるため, 脱イオン水を真空ポ ンプにかけ，気体を除いて使用した，氷球の直径は約 $3.3 \mathrm{~cm}$ であり，ビデオ伷面上の周方向に $10^{\circ}$ 間隔で測 定した各直径の平均直径からの偏りは, すべての水球に ついて $\pm 5 \%$ 以内であつた。

Fig. 1 に実験装置の概要を示す。使用流体は水道水 である、ヘッドタンクには高さ力问の 3 箇所の位置に排 水用の分があり，これらを開閉することにより，ヘッド の位置を 4 段階に変化しうる.ヘッドタンクからサージ タンクへの接続管に設けた 4 つの代切弁のうち 3 つは直 径を変えて穴を開け，オリフィスの代用とした。これら の組合せにより多くの水流量 $Q_{W}$ が設定叮能である. 各設定流量が実験中に変化しないことは重量法で確認し た. 本実験では $Q_{W}=(0 \sim 0.700) \times 10^{3} \mathrm{~cm}^{3} / \mathrm{s}$ であり， 水の断面平均速度 $V_{m}$ とパイプ内径 $D$ に基づくレイノ

昭和 61 年 7 月 29 日受付 (Received July 29, 1986)

* 大阪大学工学部 工博 (Faculty of Engineering, Osaka University, 2-1 Yamadaoka Suita 565)

*2 大阪大学 工博 (Osaka University)

*3 住友金属工業 (株) 鹿島製鉄所 (Kashima Works, Sumitomo Metal Industries, Ltd. )

*4 大阪大学大学院 (Graduate School, Osaka University) 


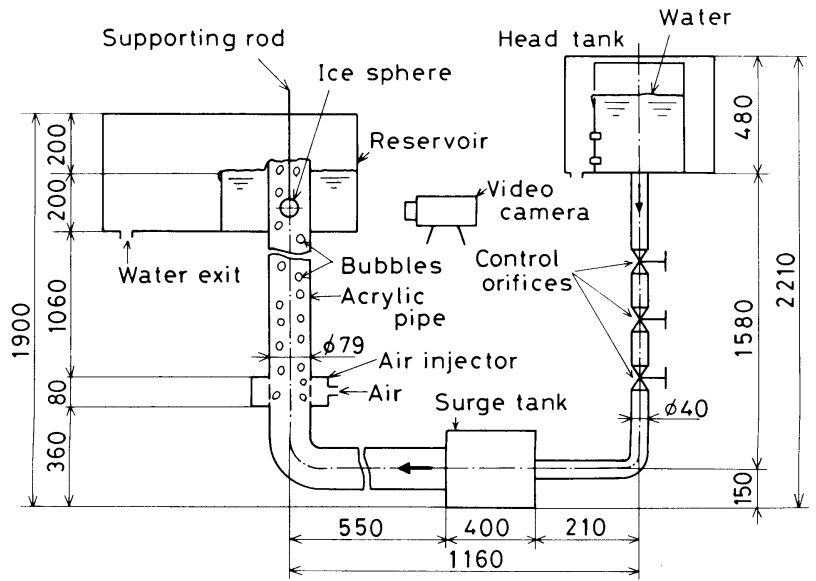

Fig. 1. Experimental apparatus.

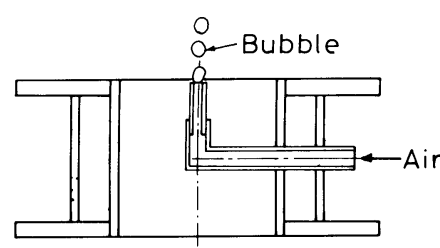

No.1

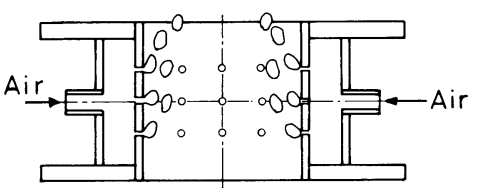

No. 2

Fig. 2. Schematic diagram of bubble generators.

ルズ数 $R e=V_{m} D / \nu \quad(\nu:$ 水の動粘度 $)$ の範井は $R e \leqq 1.2$ $\times 10^{4}, V_{m}$ と球の初期直径に基づくレイノルズ数 $R e_{p}=$ $V_{m} D_{0} / \nu$ の範囲は $R e_{p} \leqq 4.8 \times 10^{3}$ である. 水道水の温 度は試験管路前方で, 空気の温度は注入器の前方で測定 した.

アクリルパイプの試験管は，その先端がアクリル製水 槽の水面より少し上に出るようにしてある. 空気はコン プレッサーで空気注入器に送られる. 空気流量 $Q_{a}$ はガ ラス管に付けられたオリフィスを用いて $Q_{a} \fallingdotseq 1 \times$ $10^{2} \mathrm{~cm}^{3} / \mathrm{s}$ までの範囲内で設定しうる. 空気注入器には 2 種類あり，No. 1 は L 字型の黄銅管を試験管の中心に 突き出し，その先端から気泡が出るようにしたもので, No.2 は試験管のまわりから空気を注入し, 気泡を発生 させるものである (Fig. 2). No. 2 の注入器では空気 流量が小さくなると一部分からのみ気泡が発生し, 試験 管横断面内の気泡通過頻度分布に偏りが生じるので, こ のような場合にはNo. 1 を用いた。 なお空気を吹き込

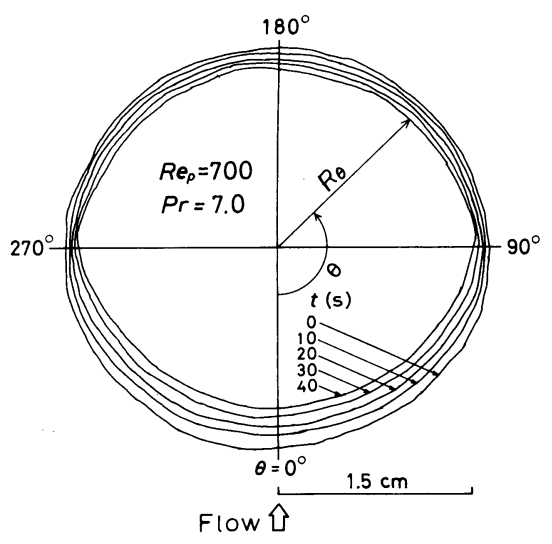

Fig. 3. An example of the time-dependent contour of a melting sphere.

む穴の直径は両者とも $1 \mathrm{~mm}$ である.

水球は氷を浮べた水中に $30 \mathrm{~min}$ 以上保持し, 水球全 体が $0{ }^{\circ} \mathrm{C}$ になつた状態で直径 $5 \mathrm{~mm}$ の支持棒に固定し, 空気注入器の上方 $1120 \mathrm{~mm}(x / D \doteqdot 14, x$ : 注入器出口 から測つた距離）に浸漬した。アクリルパイプ壁の屈折 率の影響を小さくするために，パイプの周りに水を満し た水槽を設け, 溶解の様子をビデオカメラで撮影した. その後ビデオ画面に再生し, 一定の時間間隔で半透明の 紙に氷球の輪郭を写しとつた。この眓から計算機セン ターのデジタイザーで半径の変化を測定し, 必要な処理 はすべて大型計算機（NEAC ACOS SYSTEM 1000） で行つた。

氷球の溶解は熱伝達によつて律速される。そこで溶解 速度から溶解初期の熱伝達率を計算する. Fig. 3 のよ うに水球の前方岐点から周方向座標 $\theta$ をとり, $d t$ 時間 に熱伝達によつて移動する単位面積当たりの熱量と水球 が解けることによつて失われる熱量が等しいとおけば次 


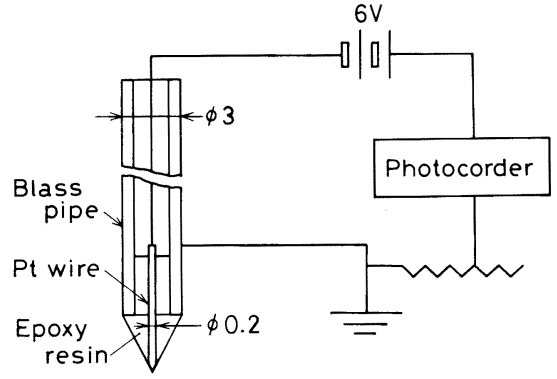

Fig. 4. The circuit of electroresistivity probe.

式が得られる。

$$
\frac{d R_{\theta}}{d t}=-\frac{h_{\theta}}{\rho_{s} \Delta H}\left(T_{b}-T_{f}\right)
$$

ここで $R_{\theta}$ は氷球の半径 $(\mathrm{cm}), t$ は時間 $(\mathrm{s}), h_{\theta}$ は熱 伝達率 $\left(\mathrm{cal} / \mathrm{cm}^{2} \mathrm{~s}^{\circ} \mathrm{C}\right), \rho_{s}$ は氷の密度 $\left(\mathrm{g} / \mathrm{cm}^{3}\right), \Delta H$ は 水の潜熱 $(\mathrm{cal} / \mathrm{g}), T_{b}$ は水のバルク温度 $\left({ }^{\circ} \mathrm{C}\right), T_{f}$ は 氷の融点 $\left({ }^{\circ} \mathrm{C}\right)$ である. 本研究では, 水球が球で近似 できる溶解初期の期間（水球半径が最大でも初期值の約 $25 \%$ 減少するまでの期間）を対象としている。この期 間における $R_{\theta}$ の減少はいたるところで時間に関して直 線的である.そこでそのこう配から $t=0$ における半径 減少率 $d R_{\theta} / d t$ を求め, これを式 (1)に代入して $h_{\theta}$ を 求め,さらに局所ヌッセルト数 $N u_{\theta}=2 R_{0} h_{\theta} / \kappa$ を計算す る. ここで $R_{0}$ は氷球の初期半径 $(\mathrm{cm}), \kappa$ は水の熱伝 導率 $\left(\mathrm{cal} / \mathrm{cms}^{\circ} \mathrm{C}\right)$ である. また氷球全体の平均ヌッセル 卜数 $\bar{N} u$ は次式に基づき数值計算で求めた.

$$
\bar{N} u=\int_{0}^{\pi} \sin \theta N u_{\theta} d \theta / 2
$$

\section{$2 \cdot 2$ 気泡観察}

Fig. 1 の装置の支持棒と水球を除いた状態で気泡を 発生させ, 水球占有位置近傍の気泡をカメラで撮影した. なお，水球前方の気泡の特性は，水球が存在する場合と しない場合とで差のないことを確認した。フィルムはト ライX（ASA 400）を用い，増感現像液（パンドール） で ASA 3200 に感度を上げた。撮影したネガフィルム を写真引き伸ばし機で拡大し，各実験条件につき 50 個 の気泡の長軸と短軸を物指しで測つた。また長軸の水平 面からの傾きを分度器で測定した。

\section{$2 \cdot 3$ 気泡通過頻度分布測定}

電気探針法によつて，水球を除いた状態で前方岐点上 流 $16 \mathrm{~mm}$ の管横断面内の気泡通過頻度分布を測定した 8). Fig. 4 に回路図を示す．探針は，先端をサンドペー パーでとがらせてエポキシ樹脂で $3 \mathrm{~mm}$ の黄銅パイプ内 に先端を出した状態で固定した直径 $0.2 \mathrm{~mm}$ の $\mathrm{Pt}$ 線で

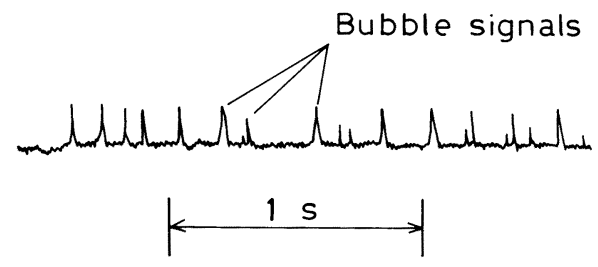

Fig. 5. Output signal of electroresistivity probe.

Table 1. Main experimental conditions.

\begin{tabular}{r|c|c|c|c|c}
\hline Run & $\begin{array}{c}Q_{a} \times 10^{-2} \\
\left(\mathrm{~cm}^{3} / \mathrm{s}\right)\end{array}$ & $\begin{array}{c}Q_{W} \times 10^{-3} \\
\left(\mathrm{~cm}^{3} / \mathrm{s}\right)\end{array}$ & $R e \times 10^{-3}$ & $R e_{p} \times 10^{-3}$ & $\begin{array}{l}\text { Air } \\
\text { injector }\end{array}$ \\
\hline 1 & & 0 & 0 & 0 & \\
2 & 0.077 & 0.102 & 1.26 & 0.526 & No. 1 \\
3 & & 0.406 & 5.01 & 2.09 & \\
4 & & 0.692 & 8.54 & 3.67 & \\
\hline 5 & & 0 & 0 & 0 & \\
6 & 0.224 & 0.102 & 1.26 & 0.526 & No. 1 \\
7 & & 0.406 & 5.01 & 2.09 & \\
8 & & 0.692 & 8.54 & 3.67 & \\
\hline 9 & & 0 & 0 & 0 & \\
10 & 0.460 & 0.102 & 1.26 & 0.526 & No. 2 \\
11 & & 0.406 & 5.01 & 2.09 & \\
12 & & 0.692 & 8.54 & 3.67 & \\
\hline 13 & & 0 & 0 & 0 & \\
14 & 0.700 & 0.102 & 1.26 & 0.526 & No. 2 \\
15 & & 0.406 & 5.01 & 2.09 & \\
16 & & 0.692 & 8.54 & 3.67 & \\
\hline
\end{tabular}

ある.この白金線を電池の一極に，黄銅パイプを十極に 接続し，その間に約 $1 \mathrm{M} \Omega$ の抵抗を加えた. Fig. 5 に 電磁オシログラフに記録された波形の 1 例を示す．急に 立ち上がつた部分が気泡の通過を表している。 パイプ内 の各半径位置の気泡通過頻度は $30 \mathrm{~s}$ あるいは $60 \mathrm{~s}$ の測 定結果から求めた.

\section{3. 実験結果と考察}

実験は多くの条件下で行つたが，ここでは主として Table 1 の条件下で得られた結果を対象に選び考察す る.

\section{$3 \cdot 1$ 気泡直径の観察}

気泡は回転だ円体のような形状をしている．そこで次 式で定義される球相当直径 $d_{3,2}$ を考える.

$$
d_{3,2}=\sum_{i=1}^{n} d_{i}{ }^{3} / \sum_{i=1}^{n} d_{i}{ }^{2}, d_{i}=\left(a_{i}+b_{i}\right) / 2 \cdots
$$

ここで $n=50, a_{i}$ と $b_{i}$ は個々の気泡の短軸と長軸であ る.まず気泡径の出現頻度 $f$ を百分率で表示した結果 の 1 例を Fig. 6 に示す. 空気流量 $Q_{a}$ が変化しても正 規分布に似た同じような分布をとつている. Table 1 に 示したほかの実験条件下でも，ある程度のばらつきはあ るものの, これらの分布と特に有意な差はみられなかつ た. 球相当直径 $d_{3,2}$ で気泡径を整理した結果を Fig. 7 に示す。 $d_{3,2}$ に及ぼす水流量 $Q_{W}$, 空気流量 $Q_{a}$ の影響 


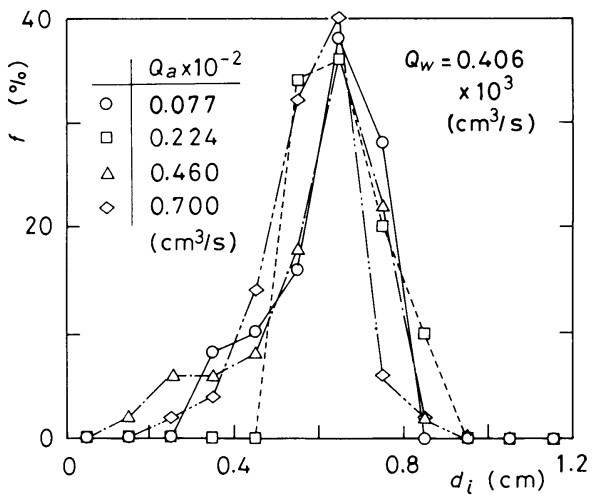

Fig. 6. Histogram of bubble diameter.

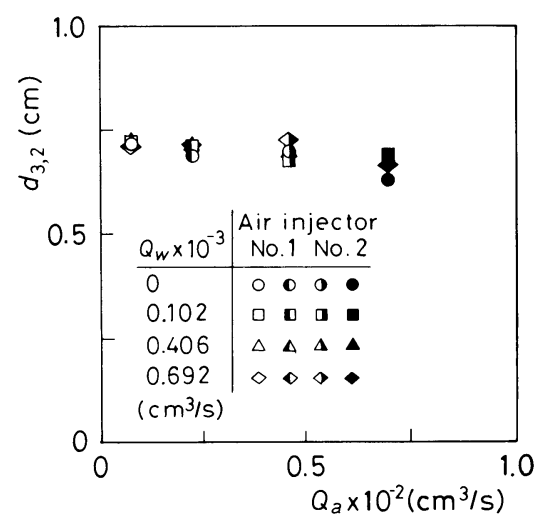

Fig. 7. Equivalent diameter of bubbles approaching an ice sphere.

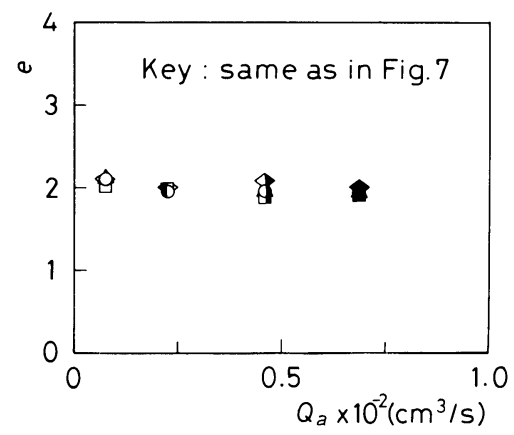

Fig. 8. Mean ellipticity of bubbles approaching an ice sphere.

はほとんどなく， $d_{3,2}$ は約 $0.7 \mathrm{~cm}$ となつている.

Fig. 8 には長軸と短軸との比の平均値 $e=\sum_{i=1}^{n} b_{i} / a_{i} n$ $(n=50)$ を, Fig. 9 には長軸と水平面とのなす角度 $\phi_{i}$ の平均值 $\phi=\sum_{i=1}^{n} \phi_{i} / n$ を示した. $e$ は約 $2, \phi$ は約 $16^{\circ}$

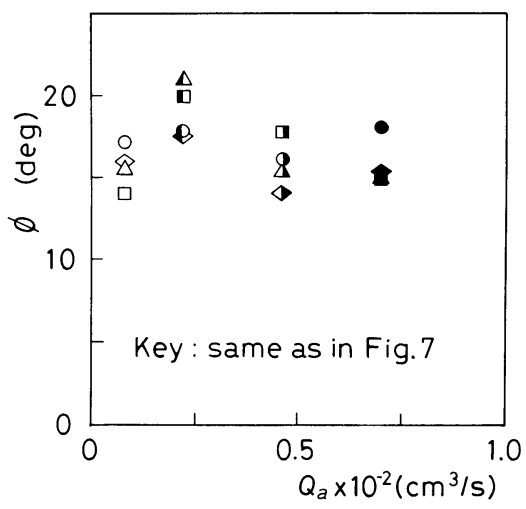

Fig. 9. Mean inclined angle of bubbles approaching an ice sphere.

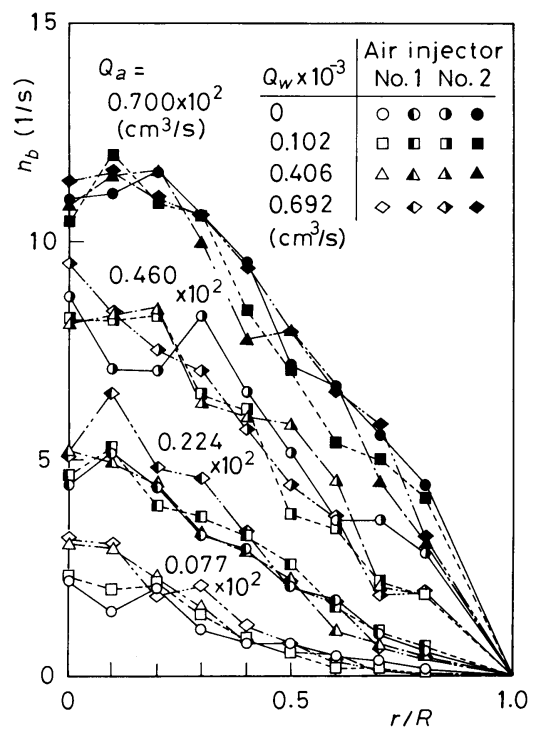

Fig. 10. Distribution of passing frequency of bubbles approaching an ice sphere.

となつており， $Q_{W}$ と $Q_{a}$ の影響はほとんどみられない. したがつて本実験条件下では， $Q_{W}$ と $Q_{a}$ が変化しても ほほ同じ大きさと形状を持つ気泡が同じ傾きをもつて氷 球にあたることになる.

\section{$3 \cdot 2$ 気泡通過頿度分布}

管横断面内の気泡通過頻度 $n_{b}$ の分布は Table 1 のい ずれの条件下でも管中心軸に関してほぼ対称な分布とな つている. 以下の結果は中心軸に関して対称な半径位置 の值を平均したものである．Fig. 10 に $n_{b}$ の分布を示 す $\left(r\right.$ : 半径座標, $R$ : 試験管路の半径). $Q_{a}$ による変化 は大きいが, $Q_{W}$ の影響はあまりみられない. 
水球の占有位置は $r / R<0.4$ であるが, 氷球まわりの 流れ場は層流境界層の厚さ ${ }^{9)}$ から推定すると，おもに $r / R \leqq 0.2$ の近寄り流れによつて支配される.この領域 では $n_{b}$ は一定值のまわりにばらついているとみなして よかろう. $0 \leqq r / R \leqq 0.2 の n_{b}$ を断面平均した值 $\bar{n}_{b}$ を $Q_{a}$ に対して示せば Fig. 11 のようになる.ここで気泡 の体積 $\pi d_{3,2}{ }^{3} / 6$ に $\bar{n}_{b}$ を乗ずれば水球にあたる気泡流量 の目安になる。物理的には $Q_{a}$ よりも水球に直接あたる 気泡流量のほうが意味を持つから, 以下の解析では $Q_{a}$ の代わりに $\bar{n}_{b}$ を用いる.

\section{$3 \cdot 3$ 局所ヌッセルト数 $N u_{\theta}$ と平均ヌッセルト数 $\bar{N} u$ に 対する予備実験（水単相流の場合）}

$3 \cdot 3 \cdot 1$ 対称性と再現性

Fig. 12 に水単相流中で溶解する水球の $N u_{\theta}$ を示す. ここで $R e_{p}$ は水球の初期直径 $D_{0}=2 R_{0}$ と水の管横断面

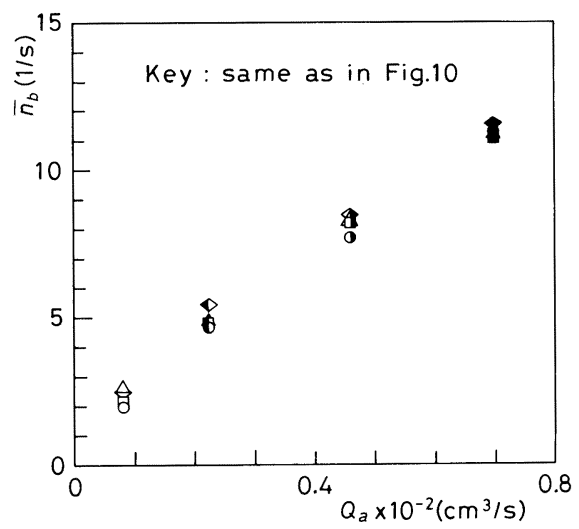

Fig. 11. Relation between the flow rate of air and mean passing frequency of bubbles.

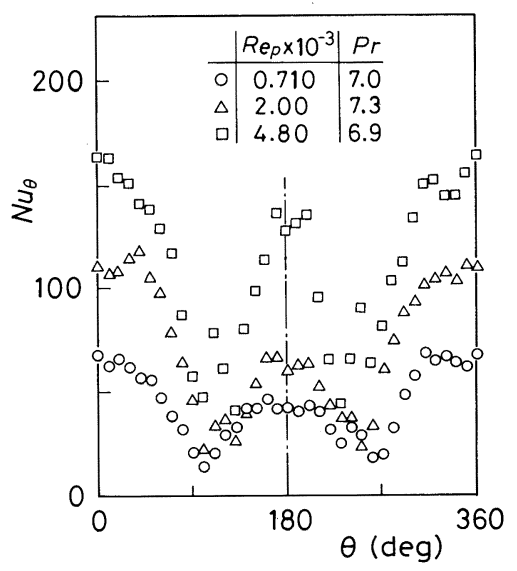

Fig. 12. Local Nusselt number of ice sphere at various values of Reynolds number.
平均速度 $V_{m}(\mathrm{~cm} / \mathrm{s})$ を代表速度とするレイノルズ数 $2 R_{0} V_{m} / \nu$ であり, $P r$ は水のプラントル数 $\mu_{b} C_{p} / \kappa$ で ある。またレは水の動粘度 $\left(\mathrm{cm}^{2} / \mathrm{s}\right), \mu_{b}$ は水の粘性係 数 $(\mathrm{P}), C_{p}$ は水の比熱 $\left(\mathrm{cal} / \mathrm{g}^{\circ} \mathrm{C}\right)$ である.ここには 示さないが, 半径の減少率は流れ方向の $\theta=0^{\circ}$ と $180^{\circ}$ を結ぶ直線(管中心軸に一致する) に関して左右対称な 分布になつている。この対称性は気泡流における実験結 果についても成立するので, 以下の $N u_{\theta}$ の図は $\theta=0^{\circ}$ 〜 $350^{\circ}$ の $10^{\circ} こ ゙ と に$ 求めた測定值を左右対称な位置で 平均した值を示している。ただし $\theta=180^{\circ} に$ に直径 $2 \mathrm{~mm}$ の支持棒があるため, この位置での值は支持棒の まわりの值を代用した。

3 回の実験による再現性の 1 例を Fig. 13 に示す. 本 測定例はもつともばらつきの大きい場合であるが，ほか のすべての実験条件下でこれよりも良好な再現性が得ら れた。

\section{$3 \cdot 3 \cdot 2$ 支持棒の影響}

水球は Fig. 1 のように $\theta=180^{\circ}$ の位置で保持してい るために，支持棒がこの近傍の $N u_{\theta}$ に影響を及ぼすこ とが考えられる.そこで氷球を流れに垂直な方向 $(\theta=$ $90^{\circ}$ ) で支持したときの結果と比較した（Fig. 14）。両 結果にほとんど差はなく, 支持棒の影響は無視してよい といえる.

$3 \cdot 3 \cdot 3 N u_{\theta}$ に関する従来の研究結果との比較

Fig. 15 で MERK の近似解析解 ${ }^{10)}$ と本実験結果とを比 較した，彼は層流境界層理論に基づき級数展開法で $N u_{\theta}$ を求めたが,この計算法では前方岐点 $\left(\theta=0^{\circ}\right)$ からは く離点前方の位置 $\left(\theta \doteqdot 90^{\circ}\right)$ までの範囲しか計算でき ない.この解は主流の乱れが非常に小さいとき, 計算時 間が短かくて，しかもかなり精度の良い解であるといわ れている ${ }^{11)} . R e_{p} \leqq 2.00 \times 10^{3}$ の測定值と計算值はよく

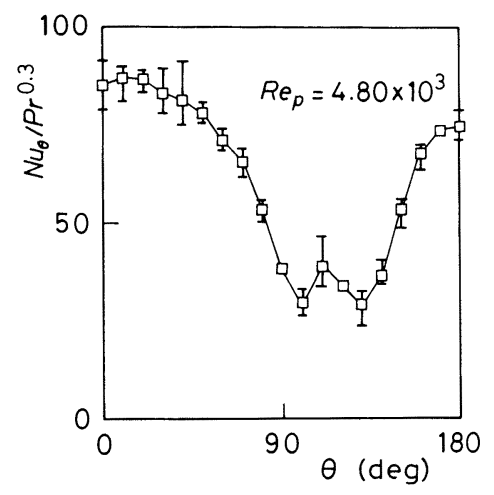

Fig. 13. The reproducibility of local Nusselt number data. 


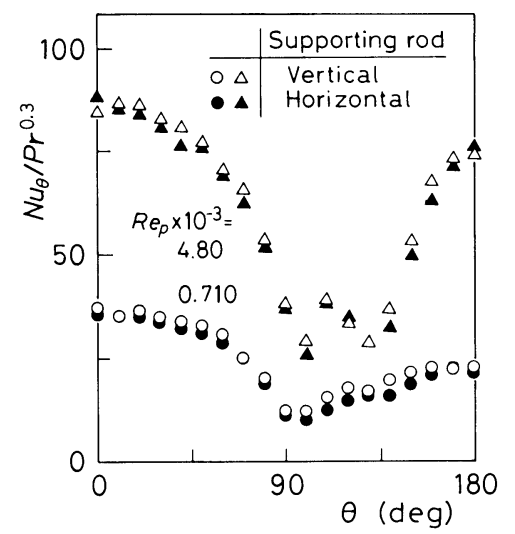

Fig. 14. The effect of the position of supporting rod on the local Nusselt number.

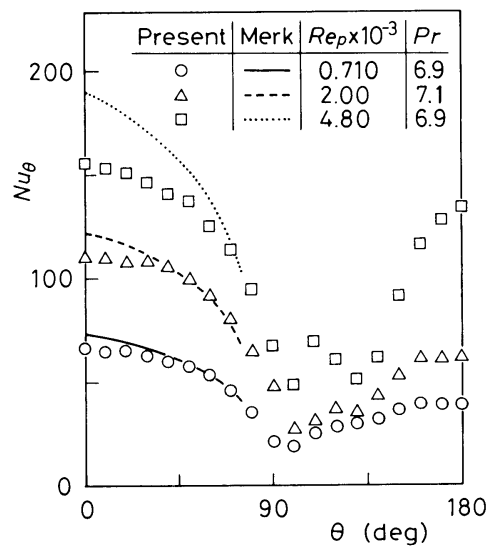

Fig. 15. Comparison of $N u_{\theta}$ between predictions and the present data.

一致しており，本測定法の妥当性が伺える.しかし $R e_{p}$ $=4.80 \times 10^{3}\left(R e=1.20 \times 10^{4}\right)$ における相違は大きいが, この場合管壁に発達する境界層は乱流に遷移している. 従来, 乱流境界層が管内を埋めつくすのは管入口からの 距離 $x$ が管直径 $D$ の 30４0 倍とされている ${ }^{12)}$. 本実 験の水球中心位置は $x / D \doteqdot 14$ であるから, 球のまわり は乱流でないとみてよいが，かなりの速度变動が誘起さ れており，このために一様流を仮定して求めた MERK の 解との間に上記相違が生じたと考えられる. Re 数の変 化に伴う入口流れ場の詳細については文献 ${ }^{12)} に$ に詳しい. $3 \cdot 3 \cdot 4 \quad \bar{N} u$ に関する従来の研究結果との比較

Fig. 16 に $\bar{N} u$ の実験結果を示す. 式(5)に示すレイノ ルズ数 $R e_{V L}$ の小さい領域を除いて測定值はほぼ直線的 に増加している. 実線はVLIET-LEPPERT ${ }^{13)}$ が本実験装置 とほほ同じ装置を用いて求めた加熱銅球から水への $\bar{N} u$

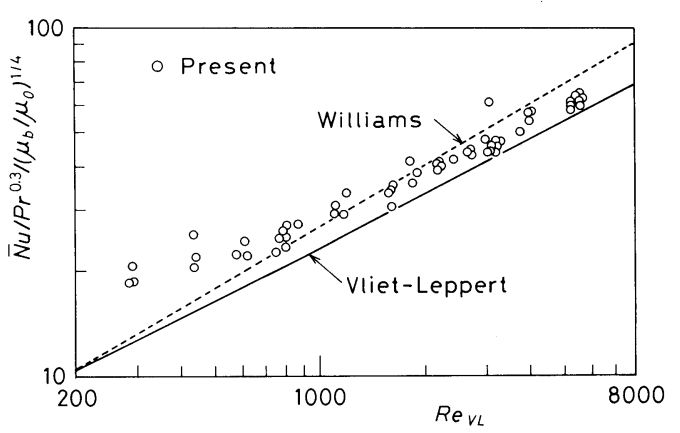

Fig. 16. Comparison of mean Nusselt number data.

の実験式であり，次式で与えられる.

$$
\left.\begin{array}{c}
\bar{N} u\left(\mu_{0} / \mu_{b}\right)^{1 / 4} / \operatorname{Pr}^{0.3}=1.2+0.53 R e_{v L}{ }^{0.54} \cdots \\
V_{v L}=Q_{w} / A_{m}, A_{m}=\pi D^{2} / 4-2 \pi R_{0}{ }^{2} / 3, \\
R e_{v L}=2 R_{0} V_{v L} / \nu
\end{array}\right\} \cdots(5)
$$

ここで $\mu_{0}$ は $0^{\circ} \mathrm{C}$ の水の粘性係数 $(\mathrm{P})$ である. 適用範 囲は $1<R e_{V L}<300000$ とされている。 また破線は WILLIAMS の実験結果であり, 文献 ${ }^{13)}$ の Fig. 5 から読み取 つた. $R e_{V L}$ の大きい領域での本測定值は実線と破線の ちょうど中間のところに位置し, 本測定法の妥当性の一 端が伺える. $R e_{V L}$ が約 600 以下の測定值は従来の結果 よりも少し大きくなるが, これは北浦ら ${ }^{14)}$ の言うよう に, 球の抵抗法則が ALLEN の法則に従う領域にあり, 球後半部の流れ場が上流から伝わる微小攪乱によつて不 安定化するために球後半部の熱伝達が促進されたためで あると考えられる，ただし微小攪乱は各装置によつて異 なり,これに応じて $\bar{N} u$ の増加量も異なると考えられる.

\section{$3 \cdot 4$ 熱伝達に及ぼす気泡の影響}

$3 \cdot 4 \cdot 1$ 局所又ッセルト数 (実験条件は Table 1 参照)

(1) 水単相流の実験結果

まず水単相流の結果を Fig. 17 に示す. $Q_{W}=0$ すな わち $R e_{p}=0$ のときには自然対流によつて球のまわりに 下降流が生じ, $N u_{\theta}$ は球の後半部で大きくなつている. $R e_{p}=0.526 \times 10^{3}$ になると球の背後に明確な循環領域が できるために，Nu は前方岐点で最大值をとつたのち， $\theta$ の増加とともに減少するが, $\theta \doteqdot 100^{\circ}$ での極小值を 経て後方岐点に向かつて増加する．極小值をとる位置は GARNER ${ }^{15)}$ の求めた層流境界層のはく離点とほぼ一致 している. しかし $R e_{p}$ が大きくなると $\theta \doteqdot 110^{\circ}$ に極大 值が現れている. 鳥居ら ${ }^{11)}$ は球の物質移動の測定を行 い，主流に乱れがある場合には，Re $e_{p}$ が臨界レイノルズ 数以下であつても局所シャーウッド数分布の極大值が $\theta \doteqdot 110^{\circ}$ 付近に現れることを観察している. 彼らは流 れの可視化に基づき, この現象をはく離点をすぎた流れ 


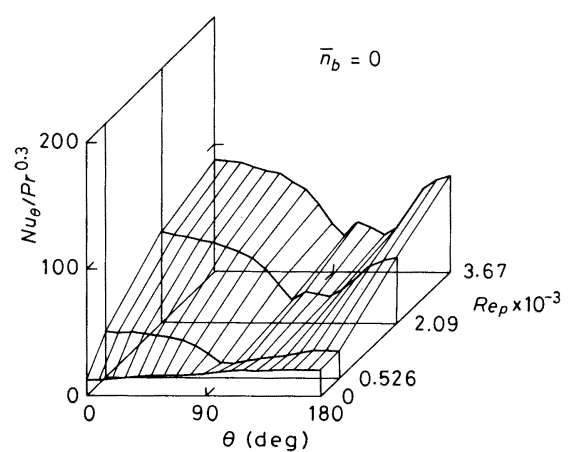

Fig. 17. Local Nusselt number in single phase flow of water.

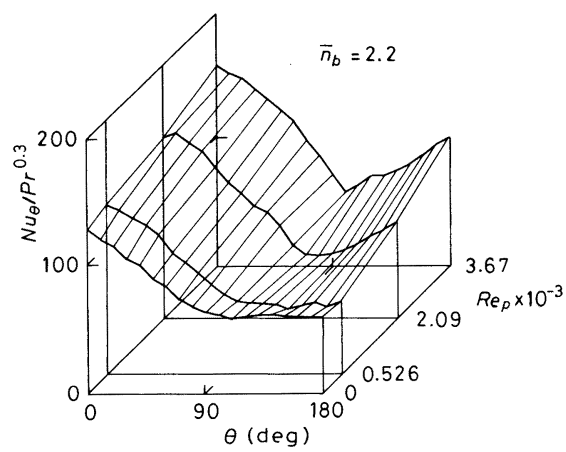

Fig. 18. Local Nusselt number in bubbling flow with mean passing frequency of $\bar{n}_{b}=2.2$.

の非定常的な再付着現象によるものであると結論した が, 本実験でも前述のように主流には大きな速度変動が あり，これが原因となつて $N u_{\theta}$ に極大值が現れたもの と考えられる.

（2）気泡が球前半部と後半部の $N u_{\theta}$ に及ぼす影響 平均気泡通過頻度 $\bar{n}_{b}=2.2\left(Q_{a}=0.077 \times 10^{2} \mathrm{~cm}^{3} / \mathrm{s}\right)$ の場合の結果を Fig. 18 に示す. わずかの気泡が衝突す るだけで，いずれの $R e_{p}$ に対しても $N u_{\theta}$ は球表面全体 にわたつて顕著に増加している. 吉田ら ${ }^{16)}$ は，水中に 水平に設置された平板に下方から気泡流を衝突させたと き, 岐点の熱伝達率は液体の速度にはほとんど関係なく, 気泡が衝突する頻度に影響されることを見出した．彼ら はこれを，境界層が気泡の衝突によつて薄くなつたため に生じたと説明している．本実験の場合にも球の前半部 における $N u_{\theta}$ の顕著な増加は上に述べた理由で概略説 明できよう。

つぎに球後半部について考える. 単相流における主流 の乱れと球からの物質移動に関する研究結果によれば, 乱れの影響は球の後半部において顕著である。これは乱

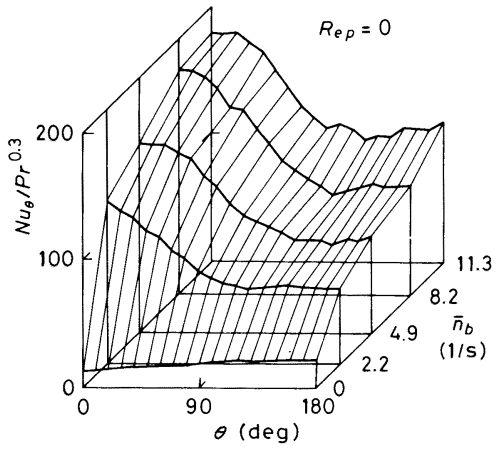

Fig. 19. The effect of mean passing frequency on local Nusselt number in still water.

れによる強い混合のために球後半部の循環領域が減少す ることに起因するといわれている ${ }^{11) 14)}$. 気泡流におい ては, 気泡に誘起された激しい速度変動に基づく循環領 域の減少によつて $N u_{\theta}$ が増加するとともに, 循環領域 に取り込まれた気泡が球後半部に衝突することに起因す る増加もある。おもにこれらの理由によつて球後半部の $N u_{\theta}$ がいたるところで大きくなつたと考えられる．球の 周りの流れ場の詳細については今後の課題としたい.

$\bar{n}_{b}$ の増加につれて $N u_{\theta}$ が増加する様相を明確に示す ために， $Q_{W}=0 \quad\left(R e_{p}=0\right)$ として $\bar{n}_{b}$ を変化させたとき の結果を Fig. 19 に掲げた，気泡による $N u_{\theta}$ の増加が 球表面全体に及んでいることがよく分かる.

（3）気泡が $N u_{\theta}$ に及ぼす影響の飽和について

Fig. 19 において $\bar{n}_{b}$ の増加に伴い気泡の影響は飽和 する傾向がみられる。この傾向は,ここには示さないが, 水球に関するレイノルズ数 $R e_{p}$ が最大の場合はもとよ

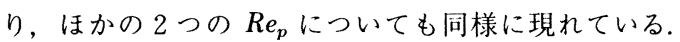
また後掲の Fig. 21 の平均ヌッセルト数の測定值におい てより顕著である。この理由を考察してみよう. 球前半 部において, 気泡が衝突して薄くなつた境界層が元の厚 さに戻るまでにはある程度の時間がかかると思われる。 ところが衝突回数が多くなると, 境界層厚さが回復する 前に次の気泡が衝突するということが起こり，その結果 として境界層厚さはある一定值に落ち着くことが考えら れる. 球前半部の $N u_{\theta}$ が飽和していく現象はこれによ つて説明できるのではないかと思われる.

一方，気泡に誘起された速度変動が球後半部の流れ場 に及ぼす影響も $\bar{n}_{b}$ がある程度増加すると飽和し，した がつて $N u_{\theta}$ も $\bar{n}_{b}$ に敏感でなくなるのであろう。これに ついては今後の課題としたい. なお， $\bar{n}_{b}$ が本実験範囲 を超えてさらに増加すると，気泡によつて球表面の水が

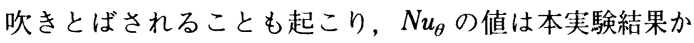




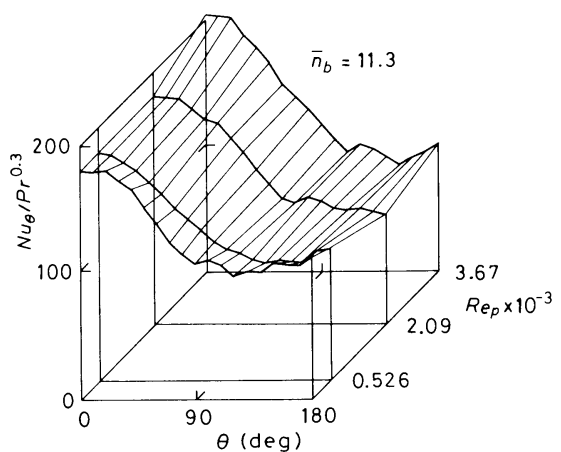

Fig. 20. The effect of Reynolds number $R e_{p}$ on local Nusselt number in bubbling flow.

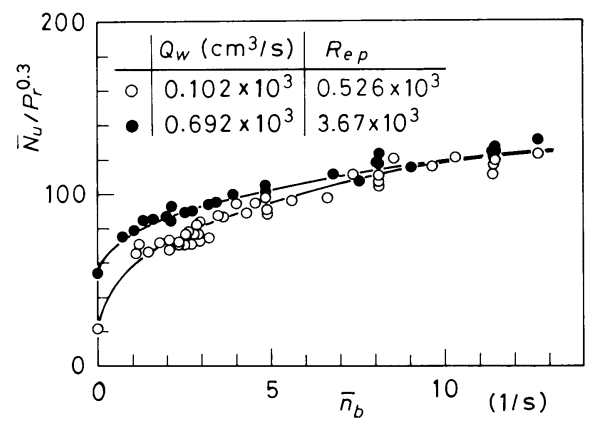

Fig. 21. Mean Nusselt number in bubbling flow.

ら予想されるものとは大きく異なる可能性がある.

（4）レイノルズ数 $R e_{p}$ が $N u_{\theta}$ に及ぼす影響

$\bar{n}_{b}$ を最大にして $R e_{p}$ を変えたときの結果を Fig. 20 に示す.単相流の Fig. 17 と比較すれば明らかなように, 気泡流において $R e_{p}$ が $N u_{\theta}$ に及ぼす影響は水単相流の 場合よりはるかに小さく， $\bar{n}_{b}$ が大きくなるほど $R e_{p}$ の 影響は小さくなる．ただし $R e_{p}$ の増加とともに球の背 後の循環流の勢いが強くなるので，この影響が Fig. 20 に示した球の後半部にわずかに認められる.

\section{$3 \cdot 4 \cdot 2$ 平均又ッセルト数 $\bar{N} u$}

$\bar{N} u$ を $\bar{n}_{b}$ に対して Fig. 21 に示す. パラメーターには $R e_{p}$ を選んだ. 局所ヌッセルト数 $N u_{\theta}$ について述べた ように, $\bar{n}_{b}$ のわずかの増加により，いずれの $R e_{p}$ の $\bar{N} u$ も顕著に増加したのち, やがて一定値に漸近するように みうけられる.また $\bar{n}_{b}$ の小さいときには $R e_{p}$ の相違に よる $\bar{N} u$ の相違は明らかであるが, $\bar{n}_{b}$ の増加とともに 両者の差は非常に小さくなる.

\section{4. 結言}

Table 1 の実験条件下では， 2 種類の発生器で得られ た気泡の氷球に衝突する前の形状はほぼ回転だ円体，寸 法は球相当直径 $d_{3,2}$ で評価して約 $0.7 \mathrm{~cm}$, 衝突角度は 約 $16^{\circ}$ とほとんど同じであつた。したがつて氷球に衝 突する前の平均気泡通過頻度 $\bar{n}_{b}$ とレイノルズ数 $R e_{p}$ を パラメーターに選び, $\bar{n}_{b}$ と $R_{p}$ がヌッセルト数に及ぼ す影響を調べた，得られた主な成果をまとめると以下の ようになる。

（1）気泡の存在によつて局所ヌッセルト数 $N u_{\theta}$ は 水球全体にわたつて顕著に増加する.これは気泡の衝突 と気泡に誘起された速度変動によつて球表面上の境界層 が薄くなるとともに, 球後半部の循環領域が減少するな どの原因によつて起こる.この結果として平均ヌッセル 卜数 $\bar{N} u$ も増加する.

（2） $\bar{N} u$ は $\bar{n}_{b}$ の増加につれて, Fig. 21 に示すよう にはじめ大きく増加するが, やがて一定值に落着き, 気 泡の影響は飽和するようになる。

（3） $R e_{p}$ が $\bar{N} u$ に及ほ影響は $\bar{n}_{b}$ が小さいときに は顕著に現れる。しかし $\bar{n}_{b}$ の増加とともにその影響は ほとんど無視できるようになる.

\section{文献}

1) 徳田昌則: 鉄と鋼, 71 (1985), S 918

2 ）西田禮次郎: 鉄と鋼, 71 (1985), S 920

3 ) 浅井滋生: 第 $100 \cdot 101$ 回西山記念技術講座（日本鉄鋼協 会編） (1984)， p. 65

4 ) Y.- C. YEN: Int. J. Heat Mass Transfer, 18 (1975), p. 917

5 ) J. Szekely, T. LeHNER and $C . W$. Chang: Ironmaking Steelmaking, 6 (1979), p. 285

6 ) $S$. Taniguchi, $M$. Ohmi, $S$. Ishiura and $S$. Yamauchi: Trans. Iron Steel Inst. Jpn., 23 (1983), p. 565

7 ) $S$. Taniguchi, $M$. Ohmi and $S$. Ishiura: Trans. Iron Steel Inst. Jpn., 23 (1983), p. 571

8 ) $K$. Sekoguchi, $H$. Fukui, $T$. Matsuoka and $K$. Nishikawa: Bulletin of the JSME, 18 (1975), p. 391

9 ) H. Schlichting: Boundary-Layer Theory, 6th ed. (1968), p. 228 [McGraw-Hill]

10) H. J. Merk: J. Fluid Mech., 5 (1959), p. 460

11）鳥居 薫, 磯部昌久, 堀部隆史, 三浦直明: 日本機械学会 論文集 B 編，46（1980），p. 944

12) A. KlEIN: J. Fluids Eng., Trans. ASME, 103 (1981), p. 243

13) G. C. Vliet and G. LePpert: J. Heat Transfer, Trans. ASME, 83 (1961), p. 163

14）北浦嘉之, 青木一雄: 化学工学, 24 (1960), p. 134

15) F. H. Garner and $R$. D. Grafton: Proc. Roy. Soc., A224, 64 (1954), p. 64

16）吉田英生, 森 康夫, 土方邦夫: 日本機械学会論文集 $B$ 編, 49 (1983), p. 1904 